\title{
A Study on the Psychometric Features of the Turkish Version of the Brief Sensation Seeking Scale (BSSS-8) for Young Adults and the Relation between Sensation Seeking and Life Satisfaction
}

Eyup Celik ${ }^{1}$, Mehmet Emin Turan ${ }^{1}$

\section{ARTICLE INFO \\ Article History: \\ Received 03.10.2015 \\ Received in revised form \\ 15.11.2015 \\ Accepted 13.12.2015 \\ Available online 01.01.2016}

\begin{abstract}
The purpose of this study is to adapt the sensation seeking scale for young adults into Turkish and to investigate if the life satisfaction of university students differ significantly in terms of sensation seeking. In addition, it was investigated whether the life satisfaction levels of university students differ significantly in terms of gender. The data for this research was collected from 570 university students. The original form of BSSS-8 consist of 8 items and 4 factors. The scale was subjected to CFA in order to determine the structural validity of its Turkish version and it was found that this version had a single factor structure. The results of the CFA suggested acceptable levels of fit indices $(\chi 2 / \mathrm{df}=4.46, \mathrm{RMSEA}=.07, \mathrm{GFI}=96, \mathrm{CFI}=.94, \mathrm{IFI}=.94, \mathrm{NFI}=.93, \mathrm{AGFI}=.93$, and NNFI $=.91)$. The reliability coefficient of the scale was found at a level of .79. Furthermore, corrected item total correlation were found to be in a range between .22 and .59. The results suggest that the single factor structure of the scale produces valid and reliable results. In addition, it was found that the life satisfaction levels of university students differ significantly in terms of sensation seeking level, but life satisfaction levels of university students do not differ significantly in terms of gender. The results showed that the life satisfaction levels of students with lower sensation seeking are higher than of students with higher sensation seeking.
\end{abstract}

(C) 2016 IJERE. All rights reserved

Keywords:

Sensation seeking, life satisfaction, adults

\section{Introduction}

It is obvious that happiness is a striking phenomenon for mankind since ancient times. The concept of happiness is addressed within the scope of structures such as life satisfaction, psychological well-being and life quality (Tuzgöl Dost, 2007). Life satisfaction, among the structures used to explain happiness, stands out as the one most commonly observed. Life satisfaction involves the whole lifespan of an individual from several perspectives. In other words, life satisfaction is not only about a specific condition but it is about the satisfaction from life in general (Özer \& Karabulut, 2007).

As theorized by Neugarten (1961), life satisfaction is defined as the state one reaches at evaluating his/her expectations (what $\mathrm{s} /$ he wants) and his/her possessions (what $\mathrm{s} /$ he possesses) (Cited in, Şener, 2008). However, it is possible to find several different definitions for life satisfaction in the literature. Tuzgöl Dost (2007) defines life satisfaction as the evaluation method adopted by an individual to assess his/her life according to the criteria s/he selected and states that the fields of satisfaction includes health, free time, job, family, money, identity and one's close circle of friends. Selçukoğlu (2001), on the other hand, defines life satisfaction as the perceived difference between one's desired wellbeing and his/her actual state of wellbeing. Yiğit, Dilmaç, and Deniz (2011) suggested that life satisfaction is one's subjective and explicit interpretation of his/her happiness and prosperity. Akın, Arslan, Celik, Kaya and Arslan (2015) found that life satisfaction was predicted positively by informational support, esteem support, motivational support, and venting support. According to the researchers, the reason behind the satisfaction is accounted for subjectively is that the data about one's life satisfaction is communicated through questions investigating if that person is happy about his/her life in general terms. Life satisfaction is also explained as the self-perception of one in terms of his/her culture and values; cognitive assessment which involves interpretation of the fields of life; and the emotional reactions between the expected and actual state (Çivitçi, 2009; Mutlu, 2012; Ünal, 2011). When the definitions and explanations ef the life satisfaction are reviewed, it is clear that one's expectations and the level these expectations are 
met, one's opinions and perceptions, the context one lives in and personal features have an effect on his/her life satisfaction. In this context, it could be suggested that one's developmental phases throughout his/her life (childhood, adolescence, young adulthood, etc.) and one's personal characteristics such as sensation seeking may have an effect on his/her life satisfaction.

Literature review showed that sensation seeking is commonly addressed in the context of stimulation theory. Stimulation theory states that individuals do not feel good as a result of lower levels of stimulation therefore they seek to elevate their stimulation to an agreeable level with sensation seeking acts (Raine, Brennan, \& Mednick, 1997). Sensation seeking is defined as the courage to discover unknown and mysterious situations or to experience such situations (Zuckerman, 2007). Nevertheless, Zuckerman defines sensation seeking as the act of seeking several, complex, strong and new excitements and experiences and taking several risks (social, financial, legal, physical risks, etc.) in order to be able to make it possible for such an experience (Zuckerman, 1994). Considering the definition of Zuckerman, individuals may differ in their sensation needs as it is the case for many other areas of life when their sensation needs are in question. Zuckerman theorized sensation seeking as a structure with 4 sub-dimensions. Among these dimensions are 1) Seeking excitement and adventure (taking physical risks, doing extreme sports, etc.), 2) Seeking experience (searching for new and exciting experiences), 3) Disinhibition (desire to take social risks and risky acts regarding health [unprotected sex, over consumption of alcohol, etc.]), 4) Boredom susceptibility (Lapsekili, Uzun, \& Ak, 2010). Individuals with higher levels of sensation seeking are likely to be interested in exciting acts such as doing bungee-jumping, being interested in mountaineering and watching horror movies (Stephenson \& Southwell, 2006). Individuals with lower levels of sensation seeking, on the other hand, prefer not to get involved with such acts which heighten stimulation level (Renfro, Antoine, \& Lawson, 2013).

Manifesting itself in varying dangerous acts, sensation seeking may guide us to the patterns behind an individual's behavior. Individuals with higher sensation seeking levels, whether the danger level of their acts is rather high, may perceive the risk level rather lower than it actually is (Zuckerman \& Kuhlman, 2000). Zuckerman stated that higher sensation seeking levels are a normal character trait except the risky behavior and says "A community will need two different individual characters. People who will read, make laws, and have a family and people who will discover and feel the excitement with an adventurous spirit like Colombus."(Cited in Lapsekili, Uzun\& Ak, 2010). Considering the personal differences, each individual has a different stimulation level and stimulation need. If a person experience heightened levels of stimulation need resulting in spiritual imbalance and if that person does not have the environmental possibilities to meet this stimulation need and fails to turn to appropriate activities, then s/he might turn to self-destructive (drug abuse and uncontrolled sex, etc.) activities which may lead to irreparable damages.

It is the case for every phase of development of a person, young adulthood also requires some developmental tasks which will influence individuals' future to a great extent. Realization of the tasks peculiar to this developmental phase coincides with the university education. An individual's ability to educate himself/herself, improve himself/herself, building long-term romantic relationships, and improving his/her social tendencies may well play an important role in his/her success in his/her career and social life after university education. In this context, young adults who face both internal and external expectations may go through a busy study schedule during university years. Growing independent from their families during this phase, individuals may want to have fun and participate in social activities the way they see fit. However, it might prove hard for young adults to meet their needs due to the insufficient opportunities their campus and its environs offer. Although they are partly independent from their families and they try to be self-sustained, they are mostly dependent on their families in terms of finances. In the light of these facts, young adults who fail to sufficiently meet their entertainment and social needs may face with low life satisfaction and in turn may have a heightened level of sensation seeking in order to make themselves happy. However, as stated in the literature, sensation seeking may lead the young adults in acts which may cause harm to themselves (drug abuse, unprotected or polygamist sex life, etc.). Moreover, an individual who cannot meet his/her sensation seeking needs through sports and arts activities and acts like discovering which do not pose danger to one's psychological and biological health may face lowered life satisfaction due to the psychological imbalance s/he experience because of the need for stimulation. Examining the literature, we could not be reached on research investigating the life satisfaction and sensation seeking relationship in university student in Turkey. Furthermore, literature review showed that there are limited amount of studies focusing on identifying the variables related with the sensation seeking. 
Therefore, it was aimed to adapt the sensation seeking scale for young adults to Turkish and to investigate if the life satisfaction of university students differ significantly in terms of sensation seeking. In addition, it was investigated if the life satisfaction levels of university students differ significantly in terms of gender.

\section{METHOD}

The research was conducted using relational survey method. Karasar (2006) states that it is possible to estimate the score of another variable when the score of one variable is estimated using the relational survey method. In this context, this study aimed to investigate the relations between sensation seeking and life satisfaction of university students using the relational survey method.

\section{PARTICIPANTS}

The data for this research was collected from 570 students of Sakarya University. Crewell (2002) suggested that an appropriate sampling method must be utilized in order to collect data from volunteering individuals and to conveniently reach to the individuals to be included into the sample during the data collection process. Thus, data was collected using appropriate sampling method in this research. The sample consists of 168 male and 402 female participants. Data was collected from participants of ages ranging from 18 to 23 and who were willing to volunteer.

\section{Measuring Tools}

\section{Life Satisfaction Scale}

This scale was developed by Diener, Emmons, Larsen, and Griffin (1985) and was adapted to Turkish language by Durak, Şenol-Durak, and Gençöz (2010). The study in which the scale was adapted to Turkish also involves a confirmatory factor analysis in order to determine its validity. According to the results of the confirmatory factor analysis, the single factor structure of the scale was confirmed and it was shown that the fit indices obtained were at an acceptable level $\left(\chi^{2} / \mathrm{df}=2.026, \mathrm{IFI}=.99\right.$, TLI= .98, CFI $=.99$, and RMSEA $\left.=.43\right)$. Nevertheless, it was found in the adaptation study that the reliability coefficient of the Turkish version of the scale was at .81 (Durak et al, 2010). According to Flynn, Schroeder and Sakakibara (1994) internal consistency coefficients of .60 and above fall in the acceptable reliability limits. Life Satisfaction Scale is a onedimensional scale consisting of 5 items which are scored using 7 -point Likert scale $(1=$ Strongly Disagree, $7=$ Strongly Agree). Life satisfaction score is obtained when each score for the items of the scale is added together. No reverse coded items are included in the scale. The lowest possible score of the scale is 5 while the highest possible score is 35 .

\section{Brief Sensation Seeking Scale for Young Adults}

Brief Sensation Seeking Scale was developed by Hoyle, Stephenson, Palmgreen, Lorch, and Donohew (2002). This scale consists of 8 items and scored using Likert scale (strongly disagree, disagree, neither disagree nor agree, agree, and strongly agree) based on self-assessment. The items of the scale, both in English and Turkish are shown in Table 1. Hoyle et al. (2002) conducted a study in order to investigate the validity and reliability of this scale on the adolescents and suggested 4 factors for this scale. Each sub-dimension of the scale consists of 2 items. On the other hand, the study in which the validity and reliability of this scale was investigated for young adults by Stephenson, Velez, Chalela, Ramirez, and Hoyle (2007) showed that the fit indices of the 4 factors model (experience seeking, boredom susceptibility, thrill and adventure seeking, disinhibition) obtained from the first order CFA and the single factor model obtained from the second order CFA are at an acceptable level. It was found that the scale has 4 sub-dimensions as a result of the first order CFA $(\chi 2(14, \mathrm{n}=257)=26.54, \mathrm{p}=0.022 ; \mathrm{CFI}=0.970$; and RMSEA = 0.059). Nevertheless, Stephenson et al. (2007) conducted a study applying second order CFA in order to determine if the factors of the scale fall under a single factor and it was found that 4 factor of the scale fall under a single factor $(\chi 2(16, n=250)=$ 268.78, $\mathrm{p}=0.025 ; \mathrm{CFI}=0.970$; and RMSEA = 0.036). The higher scores obtained from the scale indicate higher levels of sensation seeking while the lower scores obtained from the scale indicate lower levels of sensation seeking. 
Table 1. Items of the Brief Sensation Seeking Scale for Young Adults in English and Turkish

Items

1. İlginç yerleri keşfetmekten hoşlanırım.

I would like to explore strange places.

2. Evde çok fazla zaman geçirdiğimde huzursuz olurum.

I get restless when I spend too much time at home.

3. Korkutucu şeyler yapmaktan hoşlanırım.

I like to do frightening things.

4. Çılgın partilerden hoşlanırım.

I like wild parties.

5. Rotası belli olmayan ve zaman sınırı olmayan bir geziye çıkmak isterim.

I would like to take off on a trip with no pre-planned routes or timetables.

6. Heyecan verici bir şekilde ne yapacağı belli olmayan arkadaşları tercih ederim.

I prefer friends who are excitingly unpredictable.

7. Bungee-jumping yapmayı denemek isterim.

I would like to try bungee jumping.

8. Yasadışı olsa bile yeni ve heyecan verici deneyimleri yaşamayı severim.

I would love to have new andexciting experiences, even if they are illegal.

\section{The Translation Process of the Brief Sensation Seeking Scale for Young Adults}

Before the adaptation of the scale, necessary authorizations were obtained in order to translate the scale into Turkish contacting Hoyle who developed the scale. Translation of the scale into Turkish was performed by two specialists working on the guidance and psychological counseling independently and both translations were then compared in order to make necessary alterations. Then, the translated items of the scale was translated into English by a specialist from the English literature and language field to see if the scale is consistent with its original and no issues found to prevent the adaptation of the scale into Turkish.

\section{Data analysis}

A confirmatory factor analysis was conducted in order to investigate the structural validity of the scale for the data collected and Cronbach's Alpha equation was used in order to determine its reliability during the adaptation process of the brief sensation seeking scale for young adults. Corrected item-total correlations were investigated for the item analysis. Correlation analysis was used relation between sensation seeking and life satisfaction of university students while t-test was used in order to see if life satisfaction levels significantly vary according to the sensation seeking levels. In addition, it was investigated if the sensation seeking and life satisfaction levels of university students vary significantly in terms of gender using t-test. 


\section{FINDINGS}

\section{The Structural Validity of the Brief Sensation Seeking Scale for Young Adults}

Confirmatory Factor Analysis. Confirmatory factor analysis was used in order to investigate the structural validity of the scale and to see if both versions of the scale have a similar factor structure.It was first examined if the scale has 4 factors as it is the case for its original version and it was found that the model obtained do not offer acceptable fit indices as a result of the CFA. Then, the single factor structure of the scale was investigated using CFA. The results of the analysis were in line with the study conducted by Stephenson et al. (2007) which shows that all the items included in the Turkish version would fall under a single factor. The results of the confirmatory factor analysis suggested acceptable levels of fit (RMSEA $=.07$, $\mathrm{GFI}=.96, \mathrm{CFI}=.94, \mathrm{IFI}=.94, \mathrm{NFI}=.93, \mathrm{AGFI}=.93$, and NNFI $=.91)$ with $\chi 2 / \mathrm{df}(4.46)$ ratio. The results of the factor analysis are shown in Figure 1.

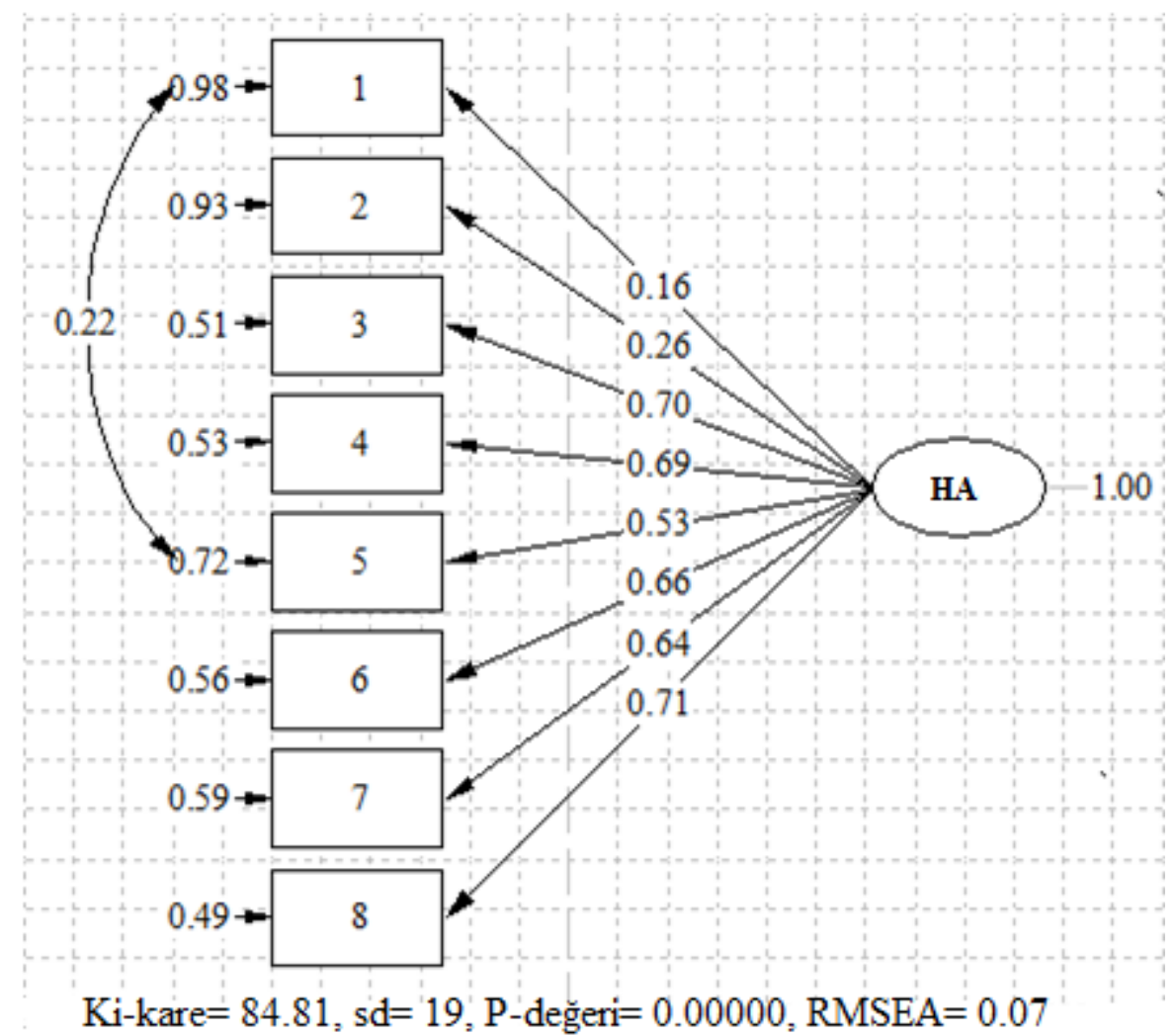

Figure 1. Results of the Confirmatory Factor Analysis (HA=Sensation Seeking)

\section{Reliability of Brief Sensation Seeking Scale for Young Adults}

Cronbach's Alpha formula was applied in order to determine the reliability of the scale. Analysis showed that the Cronbach's Alpha value was .79.

\section{Item Analysis of Brief Sensation Seeking Scale for Young Adults}

Corrected item-total correlations of the scale items were investigated for the item analysis. Findings of this analysis are shown in Table 1 . Table 1 shows that the total corrected correlations of the items were found to be in a range between .22 and .59 . 
Table 2. Results of the Corrected Total Item Correlation

\begin{tabular}{lc}
\hline Items & $r_{j x}$ \\
\hline 1 & .22 \\
2 & .27 \\
3 & .59 \\
4 & .58 \\
5 & .53 \\
6 & .56 \\
7 & .59 \\
8 & .57 \\
\hline
\end{tabular}

\section{The Relation between Life Satisfaction and Sensation Seeking}

Correlation analysis was used in order to investigate the relation between life satisfaction and sensation seeking of university students. The results of the analysis showed a negative correlation between life satisfaction and sensation seeking $(\mathrm{r}=-.11)$. The results of the correlation analysis are shown in Table 3 .

Table 3. Results of the Correlation Analysis

\begin{tabular}{lcc}
\hline Variables & 1 & 2 \\
\hline Life Satisfaction & 1 & \\
Sensation Seeking & $-.11^{* *}$ & 1 \\
$\bar{X}$ & 23.06 & 24.69 \\
$D F$ & 6.48 & 6.65 \\
\hline
\end{tabular}

$* * p<0.01$

Independent sample t-test was used in order to see if life satisfaction levels significantly differ according to the sensation seeking levels. For this purpose, participants were divided into two groups as higher level of sensation seeking and lower level of sensation seeking according to sensation seeking scores. For that, higher and lower scores of the participants' data were considered. After examining that the data were normally distributed. After that, the mean and the standard deviation scores of the sensation seeking were calculated ( $=24.69$ and $\mathrm{SD}=6.65$ ). In this frame of this distribution, 341 participants were excluded from the analysis who were between one standard deviation above the average (31.34), and one point below the average point of sensation seeking scores (18.04). Consequently, 111 participants, whose sensation seeking scores between 8 - 18.04 (\%19.47 of participants) were named as lower sensation seeking levels and 118 participants whose sensation seeking scores between $31.34-40(\% 20.70)$ of participants) were named as high sensation seeking levels.

According to the analysis results which aimed to see if life satisfaction levels of university students differ with the sensation seeking level, it was found that the average life satisfaction ( $=21.72)$ of the students with high sensation seeking levels were lower than the ones $(=24.19)$ with low sensation seeking levels. This finding is also supported by the eta squared value $\left(\mu^{2}=.35\right)$. Results are shown in Table 2. 
Table 4. Means, Standard Deviations and t-values of the Life Satisfaction Scores According to Sensation Seeking Level

\begin{tabular}{llllll}
\hline Sensation Seeking Level & $N$ & $\bar{\pi}$ & $S D$ & $t$ & $p$ \\
\hline Low & 111 & 24.19 & 6.65 & 2.70 & .007 \\
High & 118 & 21.72 & 7.15 & & \\
\hline
\end{tabular}

$D F=227$

\section{Differences in terms of Gender}

According to the result of the analysis aiming to find if life satisfaction levels of university students differ in terms of the gender. It was found that life satisfaction do not differ significantly with the gender. However, considering Table 3, it is clear that male students had higher average levels of life satisfaction $(=23.60)$ when compared to female students ( $=22.83$ ). Results are shown in Table 5.

Table 5. Means, Standard Deviations and t-values of the Life Satisfaction According to Gender

\begin{tabular}{lllllll}
\hline & Gender & $N$ & $\bar{X}$ & $S D$ & $t$ & $p$ \\
\hline Life Satisfaction & Female & 402 & 22.83 & 6.52 & -1.28 & .20 \\
& Male & 168 & 23.60 & 6.36 & & \\
\hline
\end{tabular}

$D F=568$

\section{DISCUSSION}

Adapting the sensation seeking scale for young adults into Turkish and investigating if the life satisfaction levels of university students differ significantly in terms of sensation seeking, this study shows that the Turkish version of the scale, which has 4 dimensions in its original version when assessed with CFA, has a single factor structure. It was found that the fit indices of the model which were obtained using CFA were at an acceptable level.

According to Sümer (2000), the $\chi 2 / \mathrm{df}$ ratio obtained for this model shows that the model is consistent with the data as it is below 5. Schermelleh-Engel, Moosbrugger, and Müller (2003) states that all the GFI, AGFI, CFI, IFI, RFI, and NFI fit indices of the model being above .90 and RMSEA and SRMR values being below .08 may be an indicator that the model is acceptable. In this context, the model obtained from the CFA of the sensation seeking scale for young adults and used in this research is acceptable as the $\chi 2 / \mathrm{df}$ ratio is below 5 and other fit indices (RMSEA, GFI, CFI, IFI, NFI, AGFI, and NNFI) of the model are in an acceptable range. Nevertheless, it was also found that the internal consistency coefficient of the scale is in an acceptable range according to the literature. Flynn, Schroeder, and Sakakibara, (1994) states that Cronbach's Alpha values above .60 indicate the reliability of the scale. In the light of the information above it can be said that the results obtained from the sensation seeking scale prove that this scale is a valid and reliable measuring tool to be used for young adults.

Literature review showed that there are limited amount of studies focusing on identifying the variables related with the sensation seeking. Therefore, this study is important as it adapts this scale, which will facilitate further studies about sensation seeking, into Turkish. The other purpose of this study was to investigate if the life satisfaction significantly differ with the sensation seeking level. It was found that the life satisfaction significantly differ with the sensation seeking level as a result of the analysis conducted for this hypothesis. Results showed that individuals with higher sensation seeking levels have lower life satisfaction. Literature review showed that the results obtained in this study in terms of the relation between life satisfaction and sensation seeking was inconsistent with some of the results obtained in other studies. www.ijere.comample, Oishi, Schimmack, and Colcombe (2003) suggested that Volume 1 / Issue 1 / January 2016 / 35 
sensation seeking does not directly affect life satisfaction while affecting positive feelings. The study on adolescents conducted by Çelik(2015) claims a positive relation between sensation seeking and life satisfaction. On the other hand, Stegman (2010) reported a negative relation between the sub-dimensions of sensation seeking, namely disinhibition and boredom susceptibility, and life satisfaction. Stegman's results are consistent with the results of this study. Moreover, there are research on the positive correlation of depression with sensation seeking (Carton, Jouvent, \& Widlöcher, 1992), and others indicating a negative correlation with life satisfaction (Lewinsohn, Redner, \& Seeley, 1991). It seems that the risky behaviors experienced by and results of the irresponsible way of life of adults increases the depression levels therefore making them feel bad. However, such a result may be accounted for the fact that the participants of the study are teacher candidates. According to the society teachers are supposed to show positive behaviors and lifestyles. Thus, negative lifestyles caused by sensation seeking may lead a guilty feeling in teachers therefore decreasing their life satisfaction.

This study investigated if the life satisfaction levels of university students differ significantly in terms of gender. The results of the analysis showed that the life satisfaction levels of the university students do not differ significantly with gender; however, male students had higher average levels of life satisfaction when compared to female students. This finding of the study is consistent with the study conducted by Grant, Wardle, and Steptoe (2009), while it is inconsistent with the study conducted by Dorahy, Schumaker, Simpson, and Deshpande (1996). The fact that life satisfaction of male students is higher than the one of female students may be attributed to the societal gender roles. Our society offers more independence for men, while it is not the case for women in many fields. Therefore, not able to be free due to societal gender roles, especially during the university years when students are independent from their families, female students might have lower life satisfaction when compared to male students as they feel restrained and not able to have fun as they would like to. Nevertheless, previous research indicate several changes in one's life during the transition to the university such as financial situation (Goldrick-Rab \& Han, 2011), lifestyle (Abar \& Maggs, 2010) and interpersonal relationships (Kenyon \& Koerner, 2009). These changes may prove hard for the student therefore leading to low life satisfaction. With the influence of gender roles, it might a fact that male students are more successful and resilient in the process coping with these changes and adapting to the university life when compared to female students. Thus, the life satisfaction of male students may be higher than the life satisfaction of female students.

This study also reveals some constraints along with the important findings stated above. The sample used in this study was limited only with university students. Therefore, future studies need to apply this scale which we have investigated its validity and reliability here, focusing on psychometric characteristics of people other than university students. Thus, it will be possible to tolerate the constraint of this study contributing to the validity and reliability of the scale. In addition, it is possible to contribute to the generalization of this study investigating the relation between sensation seeking and life satisfaction within samples consisting of different age groups, different ethnicities, different education levels and socioeconomic levels. Stephensonet et al. (2007) showed that the original version of the scale may be used with 4 dimensions according to the first order CFA, while the second order CFA showed that the scale can also be used with single dimension. However, as it was not possible to confirm the 4 factors structure of this scale using first order CFA, the single dimension structure was tested. The single dimension structure was confirmed with CFA. Therefore, future research needs to focus on confirming the 4 dimensional structure of the Turkish version of the scale using first order CFA and single dimension structure using second order CFA. Although it has its constraints, this study proves important for the analysis of life satisfaction and sensation seeking which are significant variables for the mental health and for offering a measuring tool for sensation seeking tendency of young adults for our culture.

\section{REFERENCES}

Abar, C. C., \& Maggs, J. L. (2010). Social influence and selection processes as predictors of normative perceptions and alcohol use across the transition to college. Journal of College Student Development, 51(5), 496-508.

Akın,A., Arslan,S., Çelik,E., Kaya,Ç. \& Arslan,N. (2015). Student academic support as a predictor of life satisfaction in university students. Eurasian Academy of Sciences Social Sciences Journal,2,38-49. 
Carton, S., Jouvent, R., \& Widlöcher, D. (1992). Cross-cultural validity of the Sensation Seeking Scale. Development of a French abbreviated form. European Psychiatry, 7, 225-234.

Creswell, J. W. (2002). Educational research: Planning, conducting, and evaluating quantitative. Prentice Hall.

Çelik, E. (2015). Mediating and moderating role of sensation seeking in the relation between selfconcealmentand life satisfaction in adolescents. Education and Science, 40(181), 349-361.

Çivitçi, A. (2009). İlköğretim öğrencilerinde yaşam doyumu: Bazı kişisel ve ailesel özelliklerin rolü. Uludă̆ Üniversitesi Ĕ̆itim Fakültesi Dergisi, 22(1), 29-52.

Dorahy, M. J., Schumaker, J. F. Simpson, P. L., \& Deshpande, C. G. (1996). Depression and life satisfaction in India and Australia. Journal of Personality and Clinical Studies, 12(1-2), 1-7.

Diener, E. D., Emmons, R. A., Larsen, R. J., \& Griffin, S. (1985). The satisfaction with life scale. Journal of personality assessment, 49(1), 71-75.

Durak, M., Şenol-Durak, E., \& Gençöz, T. (2010).Psychometric properties of the Satisfaction with Life Scale among Turkish university students, correctional officers, and elderly adults. Social Indicators Research, 99(3), 413-429.

Flynn, B., Schroeder, R., \& Sakakibara, S. (1994). A framework for quality management research and an associated measurement instrument. Journal of Operations Management, 11, 339-366. http://dx.doi.org/10.1016/S0272-6963(97)90004-8

Goldrick-Rab, S., \& Han, S. W. (2011). Accounting for socioeconomic differences in delaying the transition to college. Review of Higher Education: Journal of the Association for the Study of Higher Education, 34(3), 423-445.

Grant, N., Wardle, J., \& Steptoe, A. (2009). The relationship between life satisfaction and health behavior: A cross-cultural analysis of young adults. International Journal of Behavioral Medicine, 16, 259-268.

Hoyle, R. H., Stephenson, M. T., Palmgreen, P., Lorch, E. P., \& Donohew, R. L. (2002). Reliability and validity of a brief measure of sensation seeking. Personality and individual differences, 32(3), 401-414.

Karasar, N. (2006). Bilimsel araştırma yöntemi. Ankara: Nobel.

Kenyon, D. B., \& Koerner, S. S. (2009). Examining emerging-adults' and parents' expectations about autonomy during the transition to college. Journal of Adolescent Research, 24, 293-320. doi:10.1177/ 0743558409333021

Lapsekili, N., Uzun, Ö., \& Ak, M. (2010). Obsesif kompulsif bozukluk olgularında heyecan arama davranışı. Klinik Psikiyatri Dergisi, 170-176.

Lewinsohn, P., Redner, J., \& Seeley, J. (1991). The relationship between life satisfaction and psychosocial variables: New perspectives. In F. Strack, M. Argyle, \& N. Schwartz (Eds.), Subjective well-being (pp. 141-169). New York: Plenum Press.

Mutlu, Z. (2012). Yaşlı bireylerde yaşam tatmini ve sosyal destek ilişkisinin incelenmesi. Yayınlanmamış yüksek lisans tezi. Gazi Üniversitesi, Eğitim Bilimleri Enstitüsü, Ankara.

Oishi, S., Schimmack, U., \& Colcombe, S. J. (2003). The contextual and systematic nature of life satisfaction judgments. Journal of Experimental Social Psychology, 39(3), 232-247.

Özer. M., \& Karabulut, Ö. Ö. (2003). Yaşlılarda yaşam doyumu. Geriatri, 6(2), 72-74.

Raine, A., Brennan, P. A., \& Mednick, S. A. (1997). Interaction between birth complications and early maternal rejection in predisposing to adult violence: Specificity to serious, early onset violence. American Journal of Psychiatry, 154, 1265-1271.

Renfro, A. G., Antoine, K., \& Lawson, A. L. (2013). Sensation seeking influences on memory of positive events. North American Journal of Psychology, 15(3), 609-622. 
Schermelleh-Engel, K., Moosbrugger, H., \& Müller, H. (2003). Evaluating the fit of structural equation models: Tests of significance and descriptive goodness-of-fit measures. Methods of Psychological Research Online, 8, 23-74.

Selçukoğlu, Z. (2001). Araştırma görevlilerinde tükenmişlik düzeyi ile yalnızlı düzeyi ve yaşam doyumu arasındaki ilişkinin bazı değişkenler açısından değerlendirilmesi. Yayınlanmamış yüksek lisans tezi. Selçuk Üniversitesi, Sosyal Bilimler Enstitüsü, Konya

Stegman, S. (2010). The relation between sensation seeking and life satisfaction. Yayınlanmamış yüksek lisans tezi. Fort Hays State University.

Stephenson, M. T., \& Southwell, B. G. (2006). Sensation seeking, the activation model, and mass media health campaigns: current findings and future directions for cancer communication. Journal of Communication, 56(Suppl), S38-S56.

Stephenson, M. T., Velez, L. F., Chalela, P., Ramirez, A., \& Hoyle, R. H. (2007). The reliability and validity of the Brief Sensation Seeking Scale (BSSS-8) with young adult Latino workers: implications for tobacco and alcohol disparity research. Addiction, 102(2), 79-91. doi: 10.1111/j.13600443.2007.01958.x

Sümer, N. (2000). Yapısal eşitlik modelleri: Temel kavramlar ve örnek uygulamalar. Türk Psikoloji Yazıları, 3(6), 49-74.

Şener, Ş. (2008). Beden eğitimi öğretmenlerinin tükenmişlik ve yaşam doyumu düzeyleri. Yayınlanmamış yüksek lisans tezi. Mersin Üniversitesi, Sağlık Bilimleri Enstitüsü, Mersin.

Tuzgöl Dost, M. (2007). Üniversite öğrencilerinin yaşam doyumunun bazı değişkenlere göre incelenmesi. Pamukkale Üniversitesi Eğitim Fakültesi Dergisi, 2(22), 132-143.

Ünal, A. Ö. (2011). Lise öğrencilerinin yaşam doyumlarının bazı değişkenlere göre yordanması. Yayınlanmamış yüksek lisans tezi. Karadeniz Teknik Üniversitesi, Sosyal Bilimler Enstitüsü, Trabzon.

Yiğit, R., Dilmaç, B., \& Deniz, M. E. (2011). İş ve yaşam doyumu: Konya emniyet müdürlüğü alan araştırması. Polis Bilimleri Dergisi. 13(3), 1-18.

Zuckerman, M. (1994). Behavioral expressions and biological bases of sensation seeking. New York, Cambridge University Press.

Zuckerman, M. (2007). Sensation seeking and risky behavior. Washington, DC: American Psychological Association.

Zuckerman, M., \& Kuhlman, D. M. (2000). Personality and risk taking: common biosocial factors. Journal of Personality, 68, 999-1029. 